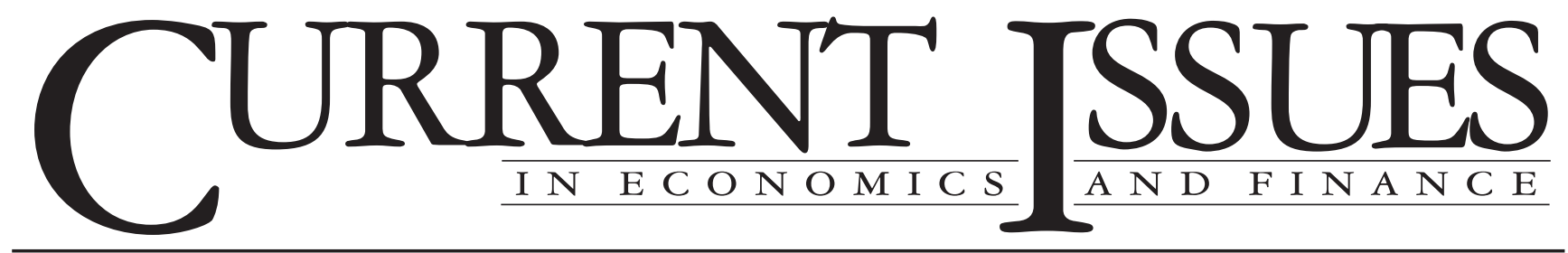

April 1997

Volume 3 Number 5

\title{
Falling Reserve Balances and the Federal Funds Rate
}

Paul Bennett and Spence Hilton

The growth of "sweeps"- a banking practice in which depository institutions shift funds out of customer accounts subject to reserve requirements-has reduced the required balances held by banks in their accounts at the Federal Reserve. This development could lead to greater volatility in the federal funds rate as banks try to manage their accounts with very low balances. An analysis of the evidence suggests that the volatility of the funds rate is rising slightly, but not enough to disrupt the federal funds market or affect the implementation of monetary policy.

During the past year, required balances held by commercial banks and other depository institutions in their accounts at the Federal Reserve have fallen sharply. This development primarily reflects the spread of "sweep" arrangements, a banking innovation that allows depository institutions to shift customers' funds out of accounts subject to reserve requirements. Recently, questions have arisen about the potential effects of the decline in required balances on the interbank federal funds market in which these balances are borrowed and lent. At issue is whether the interest rate on transactions in this market - the federal funds rateis becoming more volatile as banks try to manage their accounts with very low balances. Since the Federal Reserve implements monetary policy by influencing the federal funds rate, and the funds rate affects other short-term interest rates, a large increase in its volatility could have broader implications.

This edition of Current Issues investigates the drop in reserve balances and its effects on interest rate volatility. After describing the mechanism through which reserve balances influence the behavior of the federal funds rate, we assess the evidence suggesting that lower reserve requirements are leading to larger fluctuations in this rate. Our investigation prompts us to conclude that slightly higher short-term volatility in the federal funds rate may be resulting from the decline in reserve balances to date. Nevertheless, market participants have been adapting well to the drop in reserves and, as Federal Reserve Chairman Alan Greenspan (1997) noted in recent congressional testimony, the Federal Reserve has "not ... experienced any specific problem in implementing monetary policy."

\section{A Look at Bank Balances at the Fed}

Banks and other depository institutions typically hold accounts at their district Federal Reserve Bank for two reasons: to conduct payments activities (sending funds to, and receiving funds from, other banks) and to meet balance requirements. ${ }^{1}$ Balance requirements consist of required reserve balances and required clearing balances. (The box describes how these balances are calculated.)

Banks maintain required reserve balances in partial fulfillment of the total reserve requirement set by the Board of Governors of the Federal Reserve System. Currently, the reserve requirement equals 3 percent of the first $\$ 49.3$ million of a bank's "transaction deposits" (demand deposits and other checkable accounts) plus 10 percent of amounts beyond that. ${ }^{2}$ Banks satisfy most of this requirement through their holdings of vault cash; to calculate the amount that they must meet with balances in 
their Fed accounts, they subtract cash holdings from the total reserve requirement. The reserve balance requirement applies to the average level of a bank's end-of-day balances during a two-week "maintenance period"; endof-day balances on given days within a period may vary, although end-of-day overdrafts are penalized.

Clearing balances, the second component of required balances, are "required" only in the sense that banks contract to maintain these balances at a particular level. Banks decide whether or not they will hold a clearing balance; those that undertake this commitment typically do so to earn credits that they can use to pay for Federal Reserve priced services such as check clearing or funds transfers over the Fedwire system. Although the Federal Reserve is not allowed to pay actual interest on any balances in its accounts, these credits-the nearequivalent of interest-make clearing balances more attractive to banks. Nevertheless, because earned credits in excess of those needed to pay for Fed services are worthless, the amount of funds that it is advantageous for banks to hold in their clearing balances is limited.

Clearing balances are structured to work like reserve balances in that banks must meet average end-of-day balance amounts for the same two-week maintenance periods. ${ }^{3}$ Shortfalls are penalized, and amounts beyond the sum of required reserve balances and required clearing balances are "excess reserves" and earn no interest.

\section{Falling Reserve Balances and the Spread of Sweep Accounts}

In recent years, required balances have trended downward, reflecting a decline in required reserve balances (Chart 1). The decline in required reserve balances stems from several developments: In 1990-91, the Federal Reserve eliminated reserve requirements on time and Eurodollar deposits and, in 1992, reduced the ratio used to compute total reserve requirements on transaction deposits from 12 to 10 percent. During the

\section{Chart 1 \\ Components of Reserves and Account Balances at the Fed}

Quarterly Averages

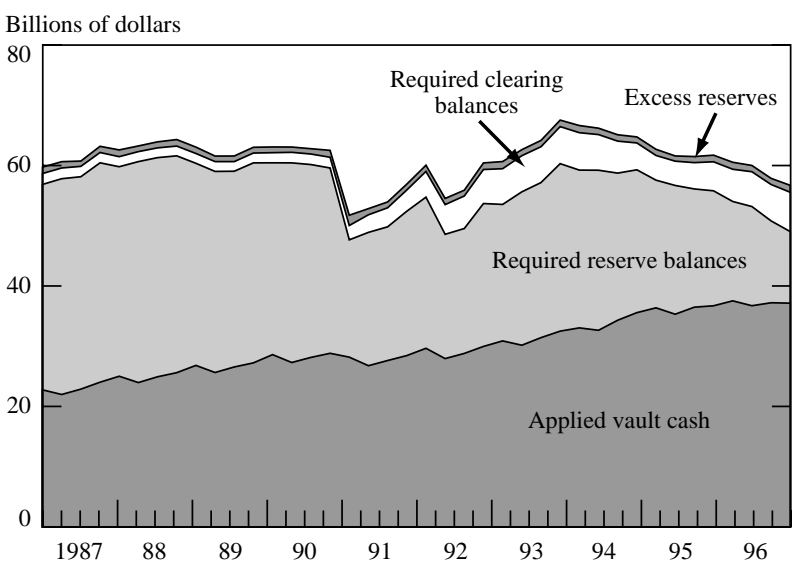

Source: Board of Governors of the Federal Reserve System.

same period when these cuts were being made, the vault cash available to fulfill total reserve requirements increased, further reducing required reserve balances. Partly in response, a number of banks opted to increase their required clearing balances in the early 1990s, but many have apparently reached the maximum balances warranted by their use of Federal Reserve payments services.

While regulatory changes largely drove the decline in required reserves in the past, the most influential factor lowering required balances recently has been the growth of sweep account arrangements. Under most sweep arrangements, funds in bank customers' retail checking accounts are swept overnight into savings accounts not subject to reserve requirements and then returned to customers' checking accounts the next business day. ${ }^{4}$ In this manner, a bank reduces its reserve requirement while

\section{How Required Balances Are Calculated}

Suppose that a bank has $\$ 200$ million in transaction deposits and \$15 million in vault cash. In March 1997, the bank faces a total reserve requirement equal to 3 percent of the first $\$ 49.3$ million in transaction deposits, plus 10 percent of amounts over that, coming to $\$ 16.549$ million. Less the vault cash, the bank's required reserve balance is $\$ 1.549$ million. Suppose in addition that the bank purchases $\$ 1,000$ worth of priced services from the Fed during each two-week maintenance period.

Given a federal funds rate of, say, 5 percent, if the bank contracted to hold a required clearing balance of $\$ 0.514$ million for two weeks, it would earn credits just covering its priced services charges. ${ }^{*}$ Thus, during the twoweek maintenance period, the bank would have to maintain end-of-day balances averaging no less than $\$ 2.063$ million, or $\$ 1.549$ million plus $\$ 0.514$ million. If the balances averaged more, then the excess amount would earn neither interest nor credits. 
depositors retain the ability to utilize their transaction accounts to make payments or withdrawals.

Sweeps have been implemented by banks in various forms for a number of years, but since 1995 their use has escalated rapidly. In lieu of collecting regular reports on such arrangements, the Federal Reserve in early 1994 began to track the amount of deposits affected at the start of each bank's sweep program or any major subsequent expansion. Summing these initial amounts gives a rough but useful indication of the size and growth of sweep accounts (Chart 2).

Using this information, we can estimate the extent of the sweeps' impact on required reserves. By February 1997, the initial values of all transaction balances subject to retail sweep arrangements had accumulated to about $\$ 184$ billion. At current reserve requirement ratios, this development implies that the spread of sweeps has reduced total required reserves by roughly $\$ 18$ billion since the end of 1993. We know that required reserve balances actually fell from \$29.4 billion in December 1993 to $\$ 11.5$ billion in February 1997, a drop of $\$ 17.9$ billion. Most of this decline can be attributed to the spread of sweeps. In recent months, transaction balances subject to sweeps have continued to rise rapidly (Chart 2), suggesting that the trend toward lower required reserve balances is likely to continue.

How will the growth of sweep accounts and the corresponding fall in required reserves affect the market in which these balances are borrowed and lent? In the next two sections, we look at the mechanism through which such developments could affect rates in the federal funds market.

\section{Bank Reserve Management and Fed Operations}

One way that a bank can obtain the funds it needs to meet balance requirements or to cover an overdraft is to borrow directly from another bank in the federal funds market, the interbank market for unsecured borrowing and lending of the balances in Fed accounts. Most of the borrowings in the federal funds market are on an overnight basis, and funds are delivered on the same day that a deal is struck. Indeed, because the market for federal funds remains active after most other financial markets have closed, it provides virtually the only opportunity for a bank to borrow funds in the market late in the day. Lenders in this market typically are banks seeking to reduce their holdings of excess reserves, which earn no interest.

The Federal Reserve Bank of New York can influence the rate on federal funds transactions by adjusting the aggregate supply of account balances through open market purchases and sales of government securities. A key objective of those open market operations is to keep the federal funds rate near the level that the Federal Open
Market Committee (FOMC) indicates is consistent with its monetary policy stance. By keeping the aggregate supply of reserves in line with demand, the Federal Reserve has been able to maintain the federal funds rate close to its desired level.

Banks' reserve management practices also play a role in keeping the federal funds rate stabilized around its target. Because balance requirements are met on a two-week daily average basis, banks can substitute balances across days. For example, if on a given day a bank finds itself with balances above the average amount it will need to meet its requirements for the overall two-week period, it can offset the surplus by holding lower end-of-day balances on subsequent days in the maintenance period. Analogously, a bank with an unexpectedly low balance one day can make it up the next, so long as the bank does not end any given day overdrawn. This ability to adjust reserve holdings across a maintenance period eases the pressure on banks to borrow or lend on any one day, reducing the likelihood that supply and demand forces will cause the federal funds rate to fluctuate very sharply.

The banks' awareness of the funds rate targeted by the Federal Reserve can further dampen volatility. Because the Fed now makes its target rate public, banks will know if the rate on a given day deviates significantly. In that event, banks can postpone or accelerate transactions in the expectation that the Fed will use its control over the supply of reserves to return the rate to the intended level on subsequent days in the maintenance period. Thus, the flexibility that banks have in timing their transactions helps ensure that deviations from the target federal funds

\section{Chart 2 \\ Sweeps of Retail Transaction Deposits into Savings Deposits}



Source: Board of Governors of the Federal Reserve System.

Notes: The chart shows the cumulative total of transaction account balances swept into money market deposit accounts at the introduction of new sweep programs. The values plotted are based on monthly averages of daily data. 
rate do not become unduly large. Note, however, that as a maintenance period draws toward its end and banks must meet their balance requirements, this flexibility diminishes and volatility often increases.

\section{Potential for Higher Federal Funds Rate Volatility}

Our look at bank reserve management and Fed operating practices has revealed how volatility in the federal funds rate is normally kept in check. We now consider how the decline in required reserves brought about by sweep accounts and other developments in the 1990s could cause volatility to rise.

With very low levels of required balances, banks will try to keep actual balances correspondingly low while avoiding end-of-day overdrafts. A bank might guard against overdrafts by holding more excess reserves, but most institutions will want to economize on their holdings of balances that bear no interest. Given the normal size and frequency of payments-related debits and credits to Fed accounts, when average balances are lower, the probability that a bank will end the day in overdraft will be higher. A bank facing a high likelihood of ending the day in a negative position must find and purchase funds in the market. Its demand for funds will be quite inelastic, particularly as the close of the day approaches. In contrast, if the bank were targeting a significantly higher balance requirement, it would face less risk of an end-of-day overdraft and have more flexibility to postpone purchases of funds until later within the maintenance period.

If enough banks are in negative positions or if the overdrafts are unexpectedly large on a given day, the increased demand for funds can lead to upswings in the federal funds rate. If, in addition, the overall supply of funds in the market is insufficient to meet the demand, the upward movement in the rate may be correspondingly larger. But even when aggregate supplies of balances appear adequate, balances may become distributed in such a way that banks with an excess supply of funds cannot be quickly matched with banks that have an excess demand. Such distributional pressures typically arise, for example, when payment flows in the banking system are heavy, such as at the end of a calendar year or on days when large numbers of securities transactions are being settled. Under such conditions, low balance requirements are likely to heighten the volatility in the funds rate by making it more difficult to relieve distributional pressures. Individual banks will be less willing to supply funds if that raises their overdraft risk, or to agree to borrow funds that are likely to push their balances substantially above the low required levels.

\section{Evidence about Volatility}

We have seen that reductions in required balances could, in principle, lead to a more volatile federal funds rate. But is there empirical support for such a link? While direct evidence on this issue is extremely limited, a look at the record suggests that a relationship, though modest, does exist.

First, bank behavior on the last day of a two-week maintenance period provides a model of how a lowbalance environment can give rise to volatility. On this day, banks with excess positions are particularly motivated to sell federal funds, which will otherwise lose economic value. ${ }^{5}$ Banks with positions in overdraft or below required maintenance period levels will need to cover them that day. The consequent inelastic buying or selling

\section{Since 1995, as the increased use of sweeps has lowered required balances, intraday volatility has ... moved upward.}

pressures experienced by these institutions have tended to create volatility in the price of funds. Indeed, the range of interest rates on federal funds transactions is typically much wider on the final days of maintenance periods.

Evidence that lower reserve balances can trigger higher volatility is also provided by the behavior of the federal funds rate at the end of 1990, when reserve requirements on wholesale deposits were eliminated. The cut in requirements coincided with a seasonal decline in required reserves and a rise in vault cash associated with year-end holidays - two events that together bring required reserve balances to their annual low point at the beginning of each new year. The consequent large drop in required balances was accompanied by an unusual rise in excess reserves and a dramatic increase in the intraday volatility of the federal funds rate. Rates on transactions ranged from near zero at times to as high as 100 percent, with some days seeing extremes in both directions. The extreme rate movements persisted for several weeks in 1991 until required reserve balances rose above their early-year low point and banks increased required clearing balances.

Further evidence of a linkage between balance requirements and volatility is offered by an apparent upward tilt in federal funds rate volatility during the past year. Using the available measure of intraday volatilitythe difference between the highest and the lowest rates observed on transactions-we can put this most recent trend in some historical perspective. Over the last two decades, monthly averages of these high-low spreads have been extremely variable, and in some periods have exhibited persistently high levels (Chart 3). Volatility was particularly marked in the early 1980 s, when the FOMC 
was targeting reserve aggregates rather than particular levels of the federal funds rate, and transactions consequently took place over a wide range of rates. In late 1990 and the first quarter of 1991, as noted earlier, volatility rose sharply after reserve requirements on wholesale deposits were dropped. Following that episode, however, volatility trended downward for several years, in part because banks were improving their account monitoring and management capabilities. ${ }^{6}$

Since 1995, as the increased use of sweeps has lowered required balances, intraday volatility has again moved upward. During the second half of 1996, this measure frequently reached 200 basis points (excluding settlement Wednesdays) on a monthly average basis, a relatively high level by recent historical standards.

\section{Why Concerns about Volatility May Be Exaggerated}

The empirical evidence suggests that low balance requirements do contribute to higher federal funds rate volatility. But even if we should expect the current rise in volatility to continue as sweeps depress banks' reserve balances further, the increase is likely to be limited in scope and effect.

The 1990-91 episode reveals that the conditions accompanying a drop in required reserves will significantly influence the degree of ensuing volatility. In 1990, reserve requirements were reduced at the same time that year-end pressures from balance sheet adjustments and large payment flows were building in the federal funds market. Moreover, because the reduction resulted from changed regulatory mandates, the effects were concentrated within a very short time span. These factors go far toward explaining the unusually severe fluctuations in the federal funds rate in this period.
By contrast, the current decline in required balances has taken place at the initiative of the banks and has been distributed over a number of quarters. Banks expanding sweep arrangements have been making their own judgments about their abilities to manage their Fed accounts with lower balances and have been able to adjust gradually to the changing conditions in the federal funds market.

\section{Even if we should expect the current rise in volatility to continue as sweeps depress banks' reserve balances further, the increase is likely to be limited in scope and effect.}

Also reassuring is that the current rise in volatility has to date been rather modest and its effects contained. Greater fluctuation in the intraday federal funds rate has not led to increased volatility in other interest rates. Moreover, because the FOMC promptly publicizes changes in the targeted federal funds rate, moderately greater volatility in the funds rate is unlikely to confuse market participants about the intended stance of monetary policy. ${ }^{7}$

\section{Conclusion}

There are valid reasons to believe that very low required balance levels induce higher federal funds rate volatility. With banks seeking to end the business day with low balances while avoiding end-of-day overdrafts, a distributional imbalance of funds among banks or an aggregate surplus or shortage of funds is more likely to trigger fluctuations in the funds rate. The historical record confirms the relationship between

\section{Chart 3}

Intraday Range of Federal Funds Rate

Nonsettlement Days

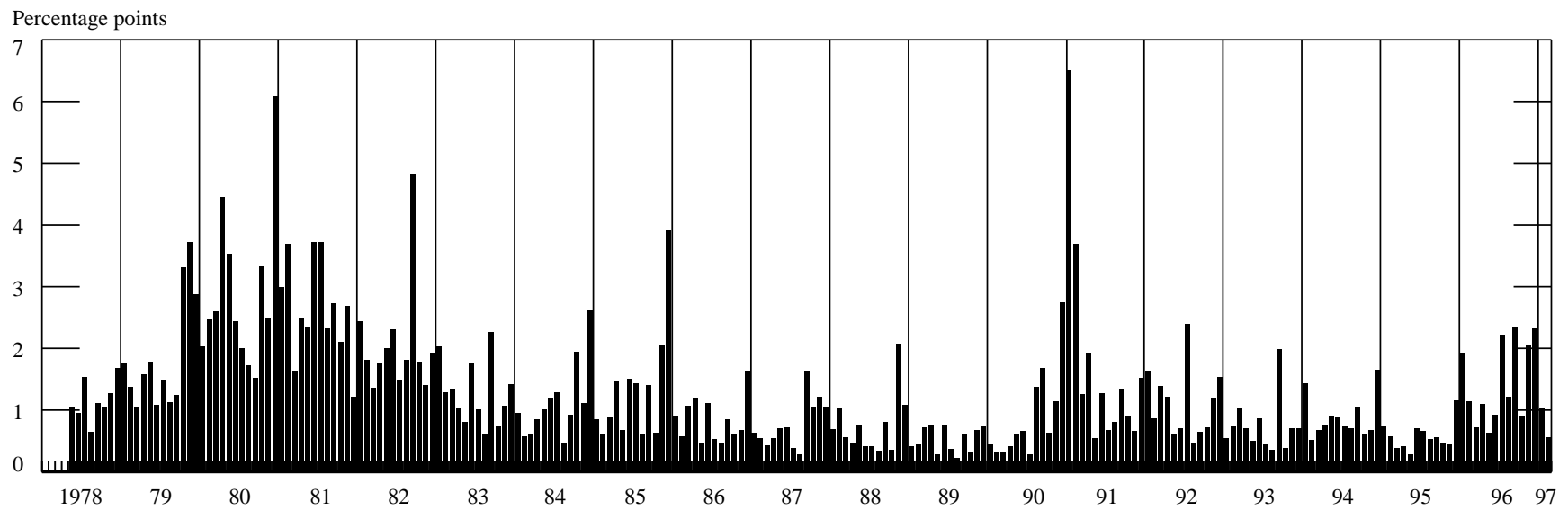

Source: Federal Reserve Bank of New York 
reserve levels and volatility: in 1990-91 and again in the years since 1994, reduced reserves have been associated with a widening of the intraday range of the federal funds rate.

To date, however, significantly lower balance requirements have not interfered with the smooth functioning of the federal funds market. The drop in balances has been gradual, and the sweep programs that are responsible for the drop have been carried out at the discretion of the banks. As a result, the observed increase in volatility has not reduced the effectiveness of banks' money market operations nor affected the implementation of monetary policy. To be sure, sweep accounts are still growing, and a continuing decline in balance requirements could over time increase federal funds rate volatility more dramatically. Nevertheless, it appears that market participants are currently adjusting well to the changing environment.

\section{Notes}

1. All depository institutions will be referred to as "banks" for the remainder of this article.

2. For more details, see Board of Governors of the Federal Reserve System (1997).

3. For more information on required clearing balances, see Stevens (1993).

4. For a more detailed description of the mechanics of different types of sweep arrangements, see Federal Reserve Bank of New York (1996).

5. Federal Reserve Board Regulation D restricts the amount of reserves a bank can carry over into the next maintenance period to 4 percent or less of its required reserves.
6. For example, since the middle of the 1980s, the Federal Reserve has made available computer screens that allow banks to track large-dollar payment systems debits and credits to their Fed accounts. The usefulness of this information system to bank money managers increased markedly in the early 1990s, when the Fed began to enter virtually all debits and credits on the real-time intraday totals transmitted to banks, essentially giving them very timely account balance estimates to compare with their internal information flows and projections.

7. One final consideration that should temper concerns about increasing volatility is related to our measure of volatility, the difference between the high and low rates on federal funds transactions in any one day. This measure may exaggerate the degree of volatility that actually exists because it captures extreme values and does not distinguish between transactions in which the dollar amount borrowed is small and transactions in which large sums change hands. Indeed, much of the recent moderate widening in the trading range appears due to smaller transactions.

\section{References}

Board of Governors of the Federal Reserve System. 1997. Federal Reserve Bulletin, February.

Federal Reserve Bank of New York. 1996. "Open Market Operations during 1995." Federal Reserve Bank of New York Annual Report, 1995.

Greenspan, Alan. 1997. Remarks before the U.S. Senate Committee on Banking, Housing and Urban Affairs. Hearing on the Federal Reserve's Semiannual Report on Monetary Policy. 105th Cong., 1st sess., February 26. Federal Document Clearing House. FDCH Political Transcripts. Washington, D.C.

Stevens, E.J. 1993. "Required Clearing Balances." Federal Reserve Bank of Cleveland Economic Review 29, no. 4.

\section{About the Authors}

Paul Bennett is Senior Vice President and Deputy Director of the Research and Market Analysis Group; Spence Hilton is Assistant Vice President in the Markets Group.

The views expressed in this article are those of the authors and do not necessarily reflect the position of the Federal Reserve Bank of New York or the Federal Reserve System.

Current Issues in Economics and Finance is published by the Research and Market Analysis Group of the Federal Reserve Bank of New York. Dorothy Meadow Sobol is the editor.

Subscriptions to Current Issues are free. Write to the Public Information Department, Federal Reserve Bank of New York, 33 Liberty Street, New York, N.Y. 10045-0001, or call 212-720-6134. Back issues are also available. 